\title{
IMMUNOPEROXIDASE TECHNIQUE USING AN ANTI-Leishmania (L.) chagasi HYPERIMMUNE SERUM IN THE DIAGNOSIS OF CULTURE-CONFIRMED AMERICAN TEGUMENTARY LEISHMANIASIS
}

Leonardo P. QUINTELLA(1), Tullia CUZZI(2), Maria de F. MADEIRA(3), Thais OKAMOTO(4) \& Armando de O. SCHUBACH(3,5)

\begin{abstract}
SUMMARY
The present study reports the production of the rabbit anti-Leishmania $(L$.$) chagasi hyperimmune serum, the standardization of the$ immunohistochemistry (IHC) technique and the evaluation of its employment in cutaneous leishmaniasis (CL) lesions diagnosed by Leishmania sp. culture isolation. Thirty fragments of active CL lesions were examined as well as 10 fragments of cutaneous mycosis lesions as control group. IHC proved more sensitive in detecting amastigotes than conventional hematoxylin-eosin (HE) stained slides: the former was positive in $24(80 \%)$ biopsies whereas the latter, in $16(53 \%)(p=0.028)$. The reaction stained different fungus species causing cutaneous mycosis. Besides, positive reaction was noticed in mononuclear and endothelial cells. Nevertheless, this finding was present in the control group biopsies. It is concluded that IHC showed good sensitivity in detecting amastigotes.
\end{abstract}

KEYWORDS: Leishmaniasis; Cutaneous; Diagnosis; Immunohistochemistry

\section{INTRODUCTION}

American tegumentary leishmaniasis (ATL) is endemic in Brazil and in other countries of the American continent, and is caused by different protozoan species of the genus Leishmania. The mucocutaneous form is caused by Leishmania (Viannia) braziliensis, a species predominating in the southeast region which shows a wide geographic distribution in Brazil and in other countries 5 .

Ideally, the diagnosis of ATL should be established by demonstration of the etiological agent. However, in Brazil, specific therapy is often instituted based on clinical and epidemiological data combined with a positive Montenegro skin test ${ }^{3}$. The presence of the parasite is commonly demonstrated by some of the so-called conventional methods for parasitological diagnosis: visualization of amastigote forms in Giemsastained smears or histopathological analysis of hematoxylin-eosin (HE)stained specimens, or isolation of promastigote forms in cultures of tissues or lesion aspirates. Nevertheless, even when combined these methods are unable to detect the microorganism in more than $30 \%$ of cases ${ }^{19}$.

More recent methods for detection of the parasite such as immunohistochemistry $(\mathrm{IHC})^{7-9,13,15-17}$ and polymerase chain reaction $(\mathrm{PCR})^{6,11,12,18}$ have been shown to be more sensitive and are beginning to be established in the laboratory routine as auxiliary or alternative methods. Considering this detection and regarding diagnostic performance parameters (sensitivity, e.g.), IHC is in between visualization methods and
PCR, as shown in a study on new world mucosal leishmaniasis ${ }^{10}$ and oldworld post-kala-azar dermal leishmaniasis ${ }^{14}$. It is also in between these techniques when we take into account cost, need for specific laboratory facilities and complexity of sample processing.

The objective of the present study was to determine the sensitivity of IHC and its usefulness on the routine diagnosis of ATL skin lesions.

\section{MATERIAL AND METHODS}

Anti-Leishmania serum was produced at the Leishmaniasis Surveillance Laboratory of Instituto de Pesquisa Clínica Evandro Chagas (IPEC), FIOCRUZ, by immunization of albino rabbits inoculated with four doses of soluble protein extracts of promastigote forms of Leishmania (Leishmania) chagasi (MHOM/BR/1974/PP75). During the immunization scheme, the level of anti-Leishmania antibodies formed was monitored by the immunodiffusion technique. Approximately 35 days after the first inoculation, the rabbits were sedated and bled by cardiac puncture.

Patients were retrospectively selected from a data bank maintained by the Leishmaniasis Surveillance Laboratory, which stores information about patients consulting at IPEC and having a diagnosis of leishmaniasis. Clinical and epidemiological data were collected and analyzed.

Thirty skin biopsy fragments obtained from 29 patients were studied. Leishmania sp. was isolated in culture from all of these fragments. The

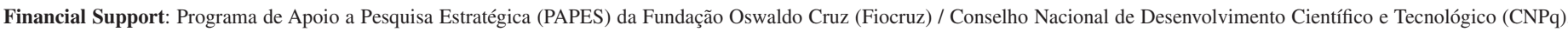
Fundação de Amparo à Pesquisa do Estado do Rio de Janeiro (FAPERJ).

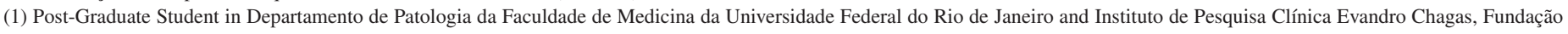
Oswaldo Cruz, Rio de Janeiro, Brazil.

(2) Departamento de Patologia da Faculdade de Medicina da Universidade Federal do Rio de Janeiro, Brazil.

(3) Laboratório de Vigilância em Leishmanioses do Instituto de Pesquisa Clínica Evandro Chagas, Fundação Oswaldo Cruz, Rio de Janeiro, Brazil..

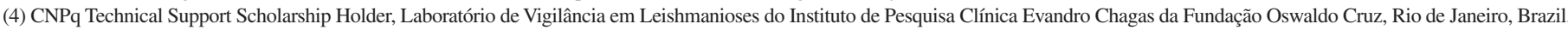

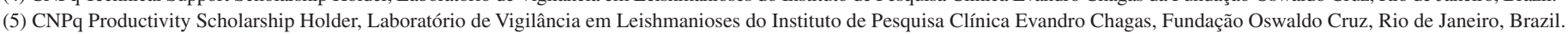

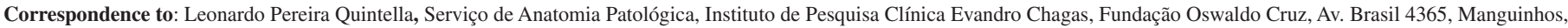
21040-900 Rio de Janeiro, RJ. Brasil. Tel.: +55.21.3865-9517. E-mail: leonardo.quintella@ipec.fiocruz.br 


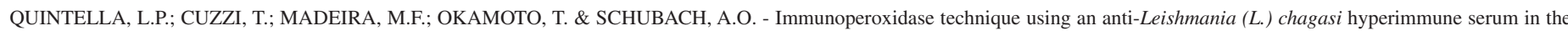
diagnosis of culture-confirmed American tegumentary leishmaniasis. Rev. Inst. Med. trop. S. Paulo, 51(2): 83-86, 2009.

histopathological sections stained with $\mathrm{HE}$ during routine diagnostic procedures were evaluated regarding the presence or absence of amastigote forms and basic inflammatory reaction. New histological sections for IHC were obtained from paraffin blocks kept at the archive of the Service of Pathological Anatomy of IPEC.

IHC by the immunoperoxidase method was performed according to the routine procedure of the Sector of Immunohistochemistry, Pathological Anatomy Service, Hospital Universitário Clementino Fraga Filho, Universidade Federal do Rio de Janeiro, which consisted of the following steps: inhibition of endogenous peroxidase with $\mathrm{H}_{2} \mathrm{O}_{2}$ and methanol, antigen retrieval with citrate buffer, $\mathrm{pH} 9.0$, in a pressure cooker for three min after boiling, followed by cooling, and inhibition of nonspecific binding with Molico ${ }^{\circledR}$ milk powder and bovine serum albumin. The specimens were incubated overnight in a refrigerator at $4{ }^{\circ} \mathrm{C}$ with the primary antibody (serum) diluted 1:800. The reaction was developed using the Universal DAKO LSAB + Detection System (catalog No. K0690, DAKO Corporation, Carpinteria, CA, USA) and diaminobenzidine as chromogen.

A case presenting numerous amastigote forms visualized by $\mathrm{HE}$ staining was used as positive control. The negative control consisted of replacement of primary hyperimmune serum by normal rabbit serum. The control group consisted of 10 skin biopsy fragments obtained from patients with fungal infection confirmed by the isolation of the etiological agent in culture and/or visualization upon histopathological analysis: sporotrichosis $(n=4)$, chromomycosis $(n=3)$, paracoccidioidomycosis $(\mathrm{n}=2)$, and histoplasmosis $(\mathrm{n}=1)$.

The IHC slides for the detection of amastigote forms were examined under a light microscope by two observers. The slides were considered to be positive when at least one morphologically compatible structure was stained, with the observation of size, shape and location inside macrophage vacuoles.

The presence of cytoplasmic staining of mononuclear inflammatory cells, especially those with morphological characteristics of macrophages, and endothelial cells was also searched for.

Positivity for fungal forms in control samples was defined as the observation of brown staining of these structures induced by the chromogenic substrate.

For statistical analysis, the sensitivity of the diagnostic tests (HE and IHC) was analyzed by comparison of proportions using the $\chi^{2}$ test for the calculation of $p$ values. The $95 \%$ confidence interval $(95 \% \mathrm{CI})$ of sensitivities was determined by calculation of the standard error of prevalence.

\section{RESULTS}

Patients included were 21 males and eight females. Twenty two had cutaneous and seven mucocutaneous disease. Lesions were single in 16 cases, ulcerated in 21 and lasted one to six months in 24. Ulcers lasted more than six months in four cases and in one case information about lesion duration was not available. Three isolates were identified as $L(V$.) braziliensis. Histopathological examination showed a granulomatous infiltrate in 26 biopsy fragments and unspecific chronic inflammation in four. Eight cases had pseudoepitheliomatous squamous hyperplasia. Plasma cells were the most abundant inflammatory cells, except the granulomas, in 22 biopsies. Five cases showed caseous necrosis. Coagulative, and both coagulative and fibrinoid necrosis were present in one case each.

Sixteen of the 30 cases studied were positive upon HE staining, corresponding to a sensitivity of the method of $53.3 \%(95 \% \mathrm{CI}=$ $36.3 \%$ to $69.4 \%$ ). Twenty-four cases tested positive by IHC (Fig. 1), corresponding to a sensitivity of $80 \%$ (95\% CI $=61.9 \%$ to $89.7 \%$ ). The difference in sensitivity between the two methods was considered significant $(p=0.028)$. All HE-positive cases were also positive by IHC. IHC also stained the fungal forms of all species studied in the control group. Positive control slides showed strong staining in virtually all tissue amastigotes.

Cytoplasmic staining of monocytic mononuclear cells was observed in 16 cases and cytoplasmic staining of endothelial cells was seen in one case of cutaneous leishmaniasis. Among controls, cytoplasmic staining of mononuclear and endothelial cells was observed in nine and two cases, respectively.

Negative control slides, in which hyperimmune serum was replaced by normal rabbit serum, did not show staining of amastigotes, fungus cells or host cells.

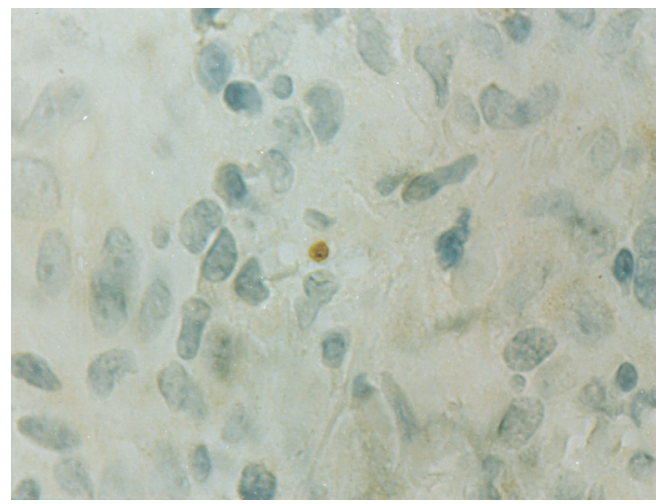

Fig. 1 - Positive immunoreaction on one single tissue amastigote. Immunoperoxidase; antiLeishmania hyperimmune serum, X 1000.

\section{DISCUSSION}

Conventional methods have shown unsatisfactory sensitivity for the parasitological diagnosis of ATL, with a sensitivity of about $70 \%$ when methods are combined ${ }^{4,15,19}$. The present report reveals that IHC is a useful and sensitive anatomopathological diagnostic method for the detection of tissue amastigote forms in active cutaneous leishmaniasis lesions when employed in routinely processed samples, and may significantly contribute to the parasitological diagnosis of ATL.

The higher sensitivity, as compared to histopathological analysis of HE-stained slides was already reported ${ }^{13,15,17}$ and might be explained by the specific staining of degenerated amastigotes that did not meet all morphological diagnostic criteria. Indeed, the application of the technique in routine diagnosis has proven to be specially useful when the presence of parasites is strongly suspected, either for the finding of highly suggestive, yet inconclusive, structures, or for the pattern of tissue 
QUINTELLA, L.P.; CUZZI, T.; MADEIRA, M.F.; OKAMOTO, T. \& SCHUBACH, A.O. - Immunoperoxidase technique using an anti-Leishmania (L.) chagasi hyperimmune serum in the diagnosis of culture-confirmed American tegumentary leishmaniasis. Rev. Inst. Med. trop. S. Paulo, 51(2): 83-86, 2009.

reaction (unpublished data). Situations in which IHC is more fruitful remains to be methodologically evaluated.

Another possible explanation for a higher sensitivity of IHC is the high color contrast between dark-brown-stained amastigotes and the light-blue-stained background ${ }^{7}$.

Positivity of the reaction in yeast cells has been previously reported ${ }^{13,15}$, and is thought to represent cross reaction between leishmanial and fungal antigens, since it was not observed in negative control slides, where the normal rabbit serum is used instead of the hyperimmune serum. This cross reaction indicates the need for careful morphological analysis of the stained structure and for correlation with fungus-specific histochemical techniques, such as periodic acid-Schiff staining and Grocott's silver impregnation, usually performed before IHC.

Cytoplasmic staining of host cells verified in the present study lacked specificity, being observed in slides of the control group. This finding opposes previous results reported by our same group ${ }^{15}$ and SOTTO et $a l .{ }^{17}$. This might be explained by the use of different detection systems or by the characteristics of the hyperimmune sera employed. Other studies regarding this specific staining, do not report the use of control groups ${ }^{1}$ or the use of normal skin as negative control ${ }^{2}$. Our present report highlights the need for adequate control group (granulomatous diseases other than leishmaniasis) and negative control of the reaction (replacement of immune serum by normal rabbit serum).

A positive control with numerous amastigote forms, which could seem inappropriate to a very sensitive technique, was used because it allows assessment of quality of the reactions. Strong staining appears in good reactions. A continuum, in the same slide, of strong staining, poor staining and no staining at all of amastigote forms can come out in tests with decaying reagents. Strong staining was observed in virtually all amastigote forms, in every slide used as positive control.

\section{RESUMO}

\section{Técnica da imunoperoxidase utilizando um soro hiperimune anti-Leishmania (L.) chagasi no diagnóstico da leishmaniose tegumentar americana confirmada por cultura}

O presente estudo relata a produção do soro policlonal de coelho antiLeishmania (L.) chagasi, a padronização da técnica de imunohistoquímica (IHQ) e sua aplicação em lesões de leishmaniose cutânea (LC) diagnosticadas por isolamento de Leishmania sp. em cultura. Foram examinados 30 fragmentos de lesões ativas de LC e 10 fragmentos de lesões de etiologia fúngica, utilizados como grupo controle. A IHQ mostrou-se mais sensível na detecção de amastigotas que a coloração em hematoxilina-eosina (HE), sendo positiva em 24 fragmentos de LC $(80 \%)$ e ao passo que a HE foi positiva em $16(53 \%)(p=0,028)$. A IHQ também marcou diferentes espécies de fungos causadoras de micoses cutâneas. Adicionalmente, verificou-se positividade no citoplasma de células mononucleares e células endoteliais. Entretanto, esse achado esteve presente no grupo controle. Conclui-se que o método de IHQ apresentou boa sensibilidade na detecção de formas amastigotas.

\section{REFERENCES}

1. AMATO, V.S.; DUARTE, M.I.; NICODEMO, A.C. et al. - An evaluation of clinical, serologic, anatomopathologic and immunohistochemical findings for fifteen patients with mucosal leishmaniasis before and after treatment. Rev. Inst. Med. trop. S. Paulo, 40: 23-30, 1998.

2. AMATO, V.S.; DE ANDRADE, H.F. \& DUARTE, M.I. - Mucosal leishmaniasis: in situ characterization of the host inflammatory response, before and after treatment. Acta trop., 85: 39-49, 2003.

3. DE OLIVEIRA-NETO, M.P.; MATTOS, M.S.; PEREZ, M.A. et al. -American tegumentary leishmaniasis (ATL) in Rio de Janeiro State, Brazil: main clinical and epidemiologic characteristics. Int. J. Derm., 39: 506-514, 2000.

4. FABER, W.R.; OSKAM, L.; VAN GOOL, T. et al. - Value of diagnostic techniques for cutaneous leishmaniasis. J. Amer. Acad. Derm., 49: 70-74, 2003.

5. FALQUETO, A. \& SESSA, P.A. - Leishmaniose tegumentar americana. In VERONESI, R. \& FOCACCIA, R., ed. Tratado de infectologia. Sao Paulo, Atheneu, 2005. v. 1, p. 1543-1557

6. GOMES, A.H.; ARMELIN, I.M.; MENON, S.Z. \& PEREIRA-CHIOCCOLA, V.L. - Leishmania (V.) braziliensis: detection by PCR in biopsies from patients with cutaneous leishmaniasis. Exp. Parasit., 119: 319-324, 2008.

7. KENNER, J.R.; ARONSON, N.E.; BRATTHAUER, G.L. et al. - Immunohistochemistry to identify Leishmania parasites in fixed tissues. J. cutan. Path., 26: 130-136, 1999.

8. LIVNI, N.; ABRAMOWITZ, A.; LONDNER, M.; OKON, E. \& MORAG, A. Immunoperoxidase method of identification of Leishmania in routinely prepared histological sections. Virchows Arch. Abt. A. Path. Anat. Histopath., 401: 147-151, 1983

9. LYNCH, N.R.; MALAVÉ, C.; IFANTE, R.B.; MODLIN, R.L. \& CONVIT, J. - In situ detection of amastigotes in American cutaneous leishmaniasis, using monoclonal antibodies. Trans. roy. Soc. trop. Med. Hyg., 80: 6-9, 1986

10. OLIVEIRA, J.G.; NOVAIS, F.O.; DE OLIVEIRA, C.I. et al. - Polymerase chain reaction (PCR) is highly sensitive for diagnosis of mucosal leishmaniasis. Acta trop., 94 55-59, 2005.

11. PIRMEZ, C.; DA SILVA TRAJANO, V.; PAES-OLIVEIRA NETO, M. et al. - Use of PCR in diagnosis of human American tegumentary leishmaniasis in Rio de Janeiro, Brazil. J. clin. Microbiol., 37: 1819-1823, 1999

12. RODGERS, M.R.; POPPER, S.J. \& WIRTH, D.F. - Amplification of kinetoplast DNA as a tool in the detection and diagnosis of Leishmania. Exp. Parasit., 71: 267-275, 1990.

13. SALINAS, G.; VALDERRAMA, L.; PALMA, G.; MONTES, G. \& SARAVIA, N.G. Detección de amastigotas en leishmaniasis cutanea y mucocutanea por el metodo de inmunoperoxidasa, usando anticuerpo policlonal: sensibilidad y especificidad comparadas con metodos convencionales de diagnotico. Mem. Inst. Oswaldo Cruz, 84: 53-60, 1989

14. SALOTRA, P.; SREENIVAS, G.; BEENA, K.R.; MUKHERJEE, A. \& RAMESH, V. - Parasite detection in patients with post kala-azar dermal leishmaniasis in India: a comparison between molecular and immunological methods. J. clin. Path., 56 840-843, 2003.

15. SCHUBACH,A.; CUZZI-MAYA, T.; OLIVEIRA, A.V. et al. - Leishmanial antigens in the diagnosis of active lesions and ancient scars of American tegumentary leishmaniasis patients. Mem. Inst. Oswaldo Cruz, 96: 987-996, 2001.

16. SELLS, P.G. \& BURTON, M. - Identification of Leishmania amastigotes and their antigens in formalin fixed tissue by immunoperoxidase staining. Trans. roy. Soc. trop. Med. Hyg., 75: 461-468,1981 
QUINTELLA, L.P.; CUZZI, T.; MADEIRA, M.F.; OKAMOTO, T. \& SCHUBACH, A.O. - Immunoperoxidase technique using an anti-Leishmania (L.) chagasi hyperimmune serum in the diagnosis of culture-confirmed American tegumentary leishmaniasis. Rev. Inst. Med. trop. S. Paulo, 51(2): 83-86, 2009.

17. SOTTO, M.N.; YAMASHIRO-KANASHIRO, E.H.; DA MATTA, V.L. \& DE BRITO, T. - Cutaneous leishmaniasis of the New World: diagnostic immunopathology and antigen pathways in skin and mucosa. Acta trop. (Basel), 46: 121-130, 1989.

18. VENAZZI, E.A.; ROBERTO, A.C.; BARBOSA-TESSMANN, I.P. et al. - Polymerase chain reaction with lesion scrapping for the diagnosis of human American tegumentary leishmaniasis. Mem. Inst. Oswaldo Cruz, 101: 427-430, 2006.
19. WEIGLE, K.A.; DE DÁVALOS, M.; HEREDIA, P. et al. - Diagnosis of cutaneous and mucocutaneous leishmaniasis in Colombia: a comparison of seven methods. Amer. J. trop. Med. Hyg., 36: 489-496, 1987.

Received: 15 May 2008

Accepted: 11 February 2009 